\title{
Constructing and contesting a Gujarati-Hindu ethno-religious identity through development programmes in an Indian province
}

\author{
Nikita Sud, University of Oxford ${ }^{1}$
}

\begin{abstract}
Through a case study of Hindu nationalism in India, this paper explores how development programmes serve as the site of construction of, as well as contestation over, religious identity. The participation of low-caste Dalits and tribal Adivasis in the mass violence perpetrated against Muslims in the Indian province of Gujarat in 2002 conveyed the impression that Hindu nationalists had achieved one of their key objectives of creating 'Hindu unity'. Cutting across social and status divisions in the local Hindu population, the Hindu nationalist party's constituency today includes its traditional upper-caste supporters, as well as lower castes. While 'the other' in the Hindu nationalist conception of community included Dalits and Adivasis as well as Muslims and Christians until the mid-1980s, the recent 'Hindu unity' agenda has seen the boundaries of 'the other' closing in around Muslims and Christians only. Despite these developments, this paper argues, continuing attempts at the construction of a unified ethno-religious identity are circumscribed and complicated by processes of contestation. Through village-level research, it shows how government actors are involved in simultaneous processes of construction as well as contestation over a Gujarati-Hindu identity through development programmes.
\end{abstract}

\footnotetext{
${ }^{1}$ Edward Simpson, Nandini Gooptu and Rochana Bajpai made several insightful comments on a draft of this paper, for which I am grateful. Thanks are also due to Achyut Yagnik for numerous conversations on Gujarat and its politics.
} 
February-April 2002 witnessed mass ethnic violence in Gujarat province, western India. Widespread national and international reporting of the communal conflagaration, in which around 2000 Muslims were killed by government-supported Hindu nationalist activists, conveyed the impression that a 'Hindutva juggernaut' of right-wing Hindu nationalism had taken over Gujarat. Hindutva refers to an ideology predicated on the idea that the Indian state, social formation and civil society should be organized according to exclusively 'Hindu' precepts. The main proponent of this ideology is a complex or family of organisations referred to as the 'Sangh Parivar'. The complex representing India's Hindu Right, includes the main national opposition party and Gujarat's governing party -- the BJP (Indian People's Party); the ideological core -- the RSS (National Volunteer Corps); the cultural-mobilisational wing -- the VHP (World Hindu Council); and the women's wing -- Rashtriya Sevika Samiti (National Service Committee). In Gujarat, the Hindutva juggernaut driven by the Hindu Right is perceived to have a profound influence over the province's government institutions and much of its media and civil society space (Gonsalves 2000, Diwanji 2003, Sikand 2004).

One of the key achievements of contemporary Gujarat's Hindutva wave seems to have been the forging of a unified Hindu identity- evident in, say, the attacks by low-caste Dalits ${ }^{2}$ and Adivasi ${ }^{3}$ tribals as 'Hindus' on Muslims in Gujarat in 2002 (Iyer et al 2002). If this reading of Gujarati society and politics is accurate, then the Hindu Right has been successful in achieving one of its key objectives. This objective is to

\footnotetext{
2 Dalit, literally meaning 'downtrodden', refers to India's former 'untouchables'. Many Dalit communities have been given the status of Scheduled Castes (SCs). The British Government first prepared a 'schedule' of socially deprived 'untouchable' castes in 1935, to increase SC representation in legislatures, government employment, and university placement. The term continues in use in the post-independence Indian Constitution and various laws.

3 Adivasi, literally meaning 'original inhabitant', refers to India's indigenous communities. Many Adivasi communities are part of a list of indigenous tribal populations (Scheduled Tribes or STs) who are entitled to much the same compensatory treatment as SCs.
} 
convert Dalit, Adivasi and other marginalised groups to the Hindutva world view, to inculcate them in Hindutva ideology, to 'integrate' them into a 'Hindu' social order, and to prevent them from aligning with other religions or regional movements, or indeed, movements for social justice and caste emancipation (Awaaz 2004). Organisations affiliated to the Hindu Right such as Sewa Bharati (Service to India), Vanvasi Kalyan Ashram (Forest-Dwellers' Welfare Organisation), Vidya Bharati (Education India), Ekal Vidyalaya (One-Teacher Schools), etc., have been entrusted with the project of building Hindu unity. They operationalise this project by running schools, dispensaries, hostels for Adivasi tribals, and other similar programmes among the marginalised sections of India's population, and by carrying out ghar vapasi (home-coming) and shuddhi (purification) programmes among these groups to reintegrate them into the Hindu fold from which they are seen to have strayed. The corollary of a movement that actively seeks to construct a united ghar (house) is the creation of a stranger/outsider. Juxtaposed with attempts to forge a Gujarati-Hindu identity is the emphasis on the Muslim and Christian as the 'other' in 'Hindu Gujarat'.

The governmental apparatus, which is led by a Hindu nationalist party, the BJP, has been implicated in the Hindutva project in Gujarat. For instance, during violence against Christians and Muslims in 1998 and 2002, the police failed to arrest Hindutva activists, politicians from the BJP encouraged arson and looting in Christian and Muslim residential localities and places of worship, and the province's top executive authorities, such as the Chief Minister, publicly exhorted Hindus to show non-Hindus their inferior place in Gujarat's social order (AIFOFDR 1999, Iyer et al 2002, Human Rights Watch 2002). Given the government's complicity in the Hindutva agenda of Hindu social and political dominance in high-profile, widely reported events such as mass violence, this paper asks, is the Gujarat state also 
involved in the Hindu Right's general objective of constructing a Gujarati-Hindu identity in more quotidian ways? To answer this question in the remainder of the paper, first I briefly set out working definitions of 'Hindu' and 'Gujarati-Hindu', the religious and ethno-religious components of this discussion. The conceptualisation of the governmental apparatus used in this paper is also elaborated. Second, a brief political history of $20^{\text {th }}$ century Gujarat outlines the context in which attempts to forge a Gujarati-Hindu identity have been made from the mid-1980s. This background to Gujarat's contemporary polity and political history indicates that since the Sangh Parivar's political arm, the BJP came to power in Gujarat in 1990, the government machinery has been made part of the project of building 'Hindu unity'. Third, the paper goes on to provide detailed ethnographic evidence to demonstrate that today, the Gujarat government is involved in wooing a broad constituency of 'Hindus', especially lower-caste Dalit and Other Backward Caste ${ }^{4}$ groups, with tools such as development programmes. The same programmes are used to define Muslims and Christians as the 'other'. The fourth and final section of the paper will examine whether the on-going construction of a Gujarati-Hindu identity has been uncontested within and outside the governmental apparatus. The paper concludes with a summary of the arguments, and indicates avenues for further research.

The primary thesis of this paper is that the Hindu Right agenda of building an ethno-religious Gujarati-Hindu unity is being fulfilled by the government through its quotidian implementation of development programmes. This thesis and the sections that support it will be substantiated through the findings of field research on an important rural development programme - the Swarnajayanti Gram Swarozgar Yojana

\footnotetext{
4 'Other Backward Castes' are those whose ritual rank and occupational status are above 'untouchables' but who remain socially and economically depressed.
} 
(SGSY) in Gandhinagar district ${ }^{5}$, Gujarat. Fieldwork for the project was conducted in July-September 2002. Sites of research included government offices in Gandhinagar, the capital city of Gujarat province; central development offices for Gandhinagar district and Gandhinagar administrative block; and three villages of Gandhinagar block pseudonymously called Ekgam, Bijapol and Trijapur. These villages were selected for study because they lie in a district where the Hindu Right is active, and because they were geographically close enough to the district headquarters and the provincial capital to allow research in multiple sites over three months. Investigations such as the one carried out in this paper hope to build a more nuanced picture of the struggles over identity and religious-ideological dominance in a site as complex as a postcolonial government and polity. They suggest that sweeping statements about the unambiguous onslaught of the Hindutva juggernaut may not illuminate much analytically.

Conceptualising 'Hindu', 'Gujarati-Hindu', 'government' and development policy in a province led by the Hindu Right

The interpretation of the term 'Hindu' commonly used by the Sangh Parivar, which also forms the working definition for this paper, is based on the theorisations of the 'father of Hindutva' - V.D. Savarkar. For Savarkar, a Hindu would be a person who regards 'Bharatavarsha, from the Indus to the Seas, as his ( $\mathrm{sic}$ ) Fatherland as well as his Holy land' (1923: 116). Thus, a person born in India cannot be a Hindu if s/he considers a non-Indian place (Mecca, Jerusalem, Rome) as his/her 'Holy land'. Following Savarkar, Hindutva ideologues believe that since Jainism, Buddhism, Veerashaivism, Arya Samaj, Sikhism, and Indian tribal cults (sic) among others, have

\footnotetext{
${ }^{5}$ Administrative region, comprising several blocks of villages
} 
their historical origins and sacred sites on Indian soil, their followers qualify as Hindus (Elst 2002). The phrase 'Gujarati-Hindu', and not merely Hindu, has been used in this paper,because in Gujarat, the Hindutva project has regional as well as religious connotations. Hindutva emblems, such as Gujarat Chief Minister Modi, have repeatedly emphasised Gujarati asmita (collective self-respect and pride), for example at election rallies after the 2002 violence, which also berated Muslims (Hindu 2002) ${ }^{6}$. I also encountered regionalist biases among Hindutva supporters in Gujarat during fieldwork on the government apparatus. For instance, while talking about the popularity of Hindutva in Gujarat, a government employee at the villagelevel indicated, 'we Gujaratis are very quami' (BV, interviewed 26/8/02). 'Quam' here refers to 'community', and the community the respondent was talking about was not of Hindus in general, but quite specifically of Gujarati-Hindus. Similarly, a village revenue official attempted to convey the absence of Muslims and Christians in his village with the words - 'there are no non-Gujaratis in this village' ( $\mathrm{T}$, interviewed 8/9/02). For this pro-Hindutva official, as for many of Gujarat's Hindutva supporters, Hinduness was very much grounded in his Gujarati identity.

This paper explores the construction of and contestation over ethnic identity in the context of development programmes. It suggests that the pro-Hindutva bias of the government's elected and non-elected actors skews the outreach of development benefits in Gujarat. At this point it is important to underline that the government - the executive authority that is at the core of the political, administrative, legal and coercive institutions that comprise the state - is neither monolithic, nor does it have volition of its own. Treating it as a homogenous entity that wholeheartedly supports

\footnotetext{
${ }^{6}$ The integration of regional pride with Hindutva is also seen in other Indian states. For instance, Mumbai (ex-Bombay), the capital of Maharashtra province, saw violent protests in NovemberDecember 2003. These were led by the regional ally of the BJP - the Hindu supremacist Shiv Sena against immigrants from Bihar 'usurping' the jobs of Maharashtrians.
} 
Hindutva in a particular manner would be overly simplistic. To be sure, there are layers of support for and opposition to Hindu nationalism in the Gujarat government, influenced by various actors' membership of caste organizations, their political and economic stake in the Hindutva project, their career ambitions, etc. Unpacking the nature of the Gujarat government and its interface, rather the varied interactions of its members with Hindutva is beyond the scope of this paper. When this paper refers to the government lending support to the Hindu Right and its ideology of Hindutva, it is referring to the highest echelons of power, viz. the office of the Chief Minister, and elected ministers and non-elected career bureaucrats chosen by him to head key departments, who have been implicated by various reports and authors in the Hindutva project (IIJ 2003; Iyer et al 2002). The collusion of the highest levels of the government apparatus in the Hindutva agenda was most visibly manifested in the antiMuslim violence of 2002. It is also being suggested here that the province's highest authorities can influence the actions of junior officials and politicians in the making of a Hindu constituency using tools such as development projects. Of course, it becomes clear in the latter sections of the paper that petty officials need not subscribe to the unitary Hindutva worldview of the likes of Gujarat's openly Hindu nationalist Chief Minister.

I now come to the final theme in this section. which has set out concepts - the specificities of development policy in a government led by the Hindu Right. Modern Indian governments have constantly been sites for dispensing patronage ${ }^{7}$ (see Bardhan 1997). Development policy is an important means of obliging political supporters and wooing electoral constituencies. Since democratic politics in India often play out

\footnotetext{
${ }^{7}$ While campaigning for elections to the Tamil Nadu legislative assembly in 2006, for instance, the main Opposition party promised supporters rice at Rupees 2 per kilogram (approximately 0.02 GBP) if voted into office. Two weeks after this announcement, the incumbent Chief Minister promised all ration card holders 10 kilograms of rice free of charge (Viswanathan 2006).
} 
along ethnic lines, ascriptive affiliations have been used by various political formations to dispense governmental patronage and ask for votes (see Kohli 1987, Rudolph and Rudolph 1987, Pai 2002). What, then, is unique about the commandeering of development policy by the BJP-led state government in its attempts to attract a Gujarati-Hindu constituency? The analytical framework of this paper is based on the contention that the BJP government's endeavour to woo lower and backward caste and Adivasi tribal groups is not merely electoral-political. It is also a step in the larger project of forging a unified Hindu identity by emphasising the notion of Hindu 'we-ness' (atmiyata). The construction of the Gujarati-Hindu identity ultimately fits into the wider agenda of re-fashioning Gujarat, even India, into a Hindu rashtra or nation-state ${ }^{8}$. The socio-political and ideological implications of the latter process are extremely significant for India, and for ideas of citizenship and nationhood within it. While democratic pluralism and secular citizenship, the normative hallmarks of modern India, are not necessarily damaged by electoral constituency building, the conscious exclusion of Muslims and Christians from development programmes goes beyond real politik. It is an ideological-political exclusion based on specific notions of who is Gujarati and who is entitled to access development through the government.

A political history of $20^{\text {th }}$-century Gujarat: setting the context for the forging of Gujarati-Hinduness

Gujarati politics in the $20^{\text {th }}$ century has tended to be conservative and dominated by upper and middle-class Hindu upper castes. During the movement for

\footnotetext{
${ }^{8}$ The formal political arm of the Hindu Right, the Bharatiya Janata Party (BJP), lost the May 2004 national election. This has, to some extent, derailed the Hindutva agenda of making India a Hindu rashtra using the Indian government apparatus. However, the BJP is in power in Gujarat till 2007, and the socio-political and cultural arms of Hindutva continue to work towards their goals all over the country.
} 
independence led by the Congress Party, the province was at the forefront of popular agitations. However, the base of these movements was quite limited. The famous Kheda farmers' agitation of 1918, for instance, was dominated by upper and middlecaste agriculturists under Congress strongman Vallabhbhai Patel. Lower-status peasants and landless labourers of the Baraiya and Patanvadiya castes were also affected by the British revenue and taxation policies and inflation that motivated the Kheda agitators, but they were not included in Gujarati nationalist movements (Hardiman 1981). Even after independence in 1947, the Gujarat Congress was dominated by the upper castes. Many of the latter supported Hindu revivalist organisations like the Arya Samaj. The line between their personal religious beliefs and their political commitments was sometimes quite blurred. Today, the Hindu Right in Gujarat has easily appropriated the Hindu revivalist legacy of the conservative post-independence Gujarati leadership. Moreover, Vallabhbhai Patel's emphasis on a strong nation and a powerful military finds resonance in the sort of strong, militarised Hindu nation-state sought by the Hindu Right (Mukta 2002).

Gujarat's relative political stability under the unquestioned dominance of the Congress Party was disturbed from the mid-1960s. Owing to national-level ideological and electoral commitments to social justice espoused by the Congress, the conservative elements from that party who were active in provincial Gujarati politics started moving towards capitalist formations such as the Swatantra Party. The Congress, which had been held together by the aim of achieving independence in the first half of the twentieth century, formally split in 1969. Much of the upper-caste, male-dominated, conservative old guard now comprised the Congress (Organisation), with Mrs. Indira Gandhi's ostensibly modernising, secular, socialism-professing group called the Congress (Requisition). With much of the Congress organisation and 
established leadership in the Congress (O), Mrs. Gandhi set about building a mass party through populist appeals. She coined the slogan 'garibi hatao' (remove poverty), which brought her to power as the country's Prime Minister in 1971. She then broadened the leadership base of the party, actively bypassing the remaining uppercaste leaders whose political ambitions might have clashed with hers. From the midseventies, under Indira Gandhi's guidance, a distinct pattern of backward castes and candidates from religious minorities being put forth on Congress tickets emerged in Gujarat. Thus, for the 1980 State Assembly elections, the Congress (Indira) put up candidates from these ethnic groups in 111 out of the 182 available seats, and got 86.5 per cent elected. Muslim, Christian, tribal, backward and lower-caste Members of Legislative Assembly belonging to the Congress increased from 38.7 per cent in 1967 to 68.6 per cent in 1980 . Obviously, the number of high-caste - Brahmin, Patidar and Bania - MLAs in the State Assembly declined correspondingly. In June 1980, a Congress (I) government was sworn in under the Chief Ministership of Madhavsinh Solanki, himself from a backward caste. Only five of Solanki's Cabinet members had previous ministerial experience, with many new ministers representing socially, politically and economically disadvantaged groups. The latter also came to dominate the 95 patronage structures, such as public sector undertakings, government boards and corporations, in 1980-1985 (Sheth 1998: 27). The strategy of this period to promote lower and backwards-caste Hindus and religious minorities politically was more than just an electoral ploy engineered in New Delhi or the Gujarat capital. It represented the widening of political space through the democratic electoral process. It reflected, as well as encouraged, the aspirations for socio-political mobility and power of several groups. 
A sense of alienation created by three phenomena - loss of political power, perceived potential loss of social dominance and loss of control over state structures of economic and political patronage - propelled Gujarat's upper-caste Hindus, politically divided since the Congress split in 1969 , aggressively to support two 'antireservation' agitations in 1981 and 1985. This was an 'elite revolt' ${ }^{9}$ against the Congress-led provincial government's decision to implement reservation of 21 per cent of government jobs and graduate education for lower-caste Dalits and 28 per cent for backward-caste OBCs. The 1981 anti-lower-caste violence spread from the industrial metropolis of Ahmedabad to the towns of 18 out of 19 administrative districts of Gujarat (Nandy et al 1995: 103). The violence of 1985 began as an agitation of upper-caste college students against reservations for backward-caste Hindus in graduate education. It was soon taken over by the student wing of the Hindu Right - the ABVP (Akhil Bharatiya Vidyarthi Parishad or All-India Students Federation) - and by other upper-caste Hindu groups. It then became a general movement against lower castes and Muslims. There is evidence that upper-caste associations issued circulars to members to attack these groups and 'teach them a lesson' for daring to aspire to positions that had, until then, been the domain of the Brahmins, Banias and Patidars (Narayanpura Patel Yuvak Mandal 1985, in Dave 1990: Annexure VII: 22). We also know that prominent members of the Gujarat BJP were actively involved in instigating violence in 1981 and 1985 (Dave 1990: 139). The idea of the anti-reservation agitation was not just to persecute a supposedly aggrandising 'other'; it was also to oust the incumbent government, dominated by lower and backward castes, Adivasi tribals and Muslims, from power. The 1985

\footnotetext{
${ }^{9}$ Term used by Corbridge and Harriss (2000)
} 
violence left 210 lower-caste Dalits and Muslims dead. It subsided only with the forced resignation of Chief Minister Solanki.

During both the 1981 and 1985 anti-reservation agitations, the Hindu upper castes found political leadership in the Sangh Parivar. The Parivar was able to bring together much of Gujarat's political opposition in an attempt to oust the Congress. By 1983, however, it had realised that upper-caste identity politics would not bring it more than a quarter of Gujarat's votes ${ }^{10}$. The constituency of backward and lowercaste Hindus, tribals and Muslims tapped by the Congress, on the other hand, united 70-75 per cent of Gujarat's population. Clearly, the upper-caste identity would be inadequate for taking over political power. With this realisation, the Parivar started promoting an alternative socio-political identity in Gujarat and in India as a whole. This identity was based on Hindu unity, irrespective of caste. Moreover, it poached a large part of the Congress' erstwhile electoral constituency, minus of course the province's 9 per cent Muslim population. Apart from being a politico-electoral exercise, the Hindu unity ideal also approximated the ideological aim of Hindutva, which seeks to build a united Hindu nation and culture. Lower-caste Dalits, the backward castes and tribal Adivasis are very much part of the composite Hindu identity inspired by the likes of Savarkar.

Several methods were used from 1983-84 to build a unified Hindutva constituency. For instance, Dalits were invited to attend Hindu religious programmes such as Rath Yatras or chariot processions of Hindu deities, till then closed to the former 'untouchables'. Youth groups were organised in which the cultural wing of the Hindu Right, the VHP, asked young people to dedicate themselves to the abolition of

\footnotetext{
${ }^{10}$ At the turn of the twentieth century, upper caste Brahmins, Banias and Patidars numbered 5.75, 6.06 and 15.62 percent of Gujarat's population respectively (Bombay Gazetteers 1899, in Sanghavi 1996: 64). Since no caste-based censuses have been carried out in independent India, only approximate caste figures based on earlier censuses are available to us today.
} 
untouchability and to work for the all-round development of their 'economically and socially backward Hindu brothers' (VHP 1986). Schools began to be built in remote tribal areas to propagate the Hindu values and culture usually adhered to by the uppercaste Brahmins. In fact, towards the end of the 1985 'anti-reservation' agitation, orchestrated by the Hindu Right, most of the victims were Muslims and not lower or backward-caste Hindus. That the Hindu unity strategy was being effectively implemented is evident from a bout of communal violence that broke out in 1986 in Ahmedabad, during the annual chariot procession of Lord Jagannath. This episode witnessed lower-caste Dalits and Muslims fighting against each other, a significant change from the 1981 anti-reservation violence in which these groups had shown solidarity. One of the reasons for the Sangh Parivar's success in mobilising lower castes could be the apparent capacity of Hindutva to provide a channel for upward social mobility and respect within Hindu society (Nandy et al 1995). Judging by the BJPs electoral successes from 1990, the Hindu unity strategy has paid off. The remainder of this paper explores how, under the political dominance of the BJP, the government of Gujarat has been pressed into action to further this strategy.

'There are no non-Gujaratis in this village'. The government and the building of a

\section{Gujarati-Hindu constituency}

Being in government has facilitated the Hindu Right's efforts to woo lower castes; it has also enabled active discrimination against non-Hindus in the disbursement of development benefits. In this way, development has contributed to the solidifying of boundaries around the 'us' and the 'other'. In the following pages, I will substantiate these points through a study of one component of India's vast poverty alleviation policy - the SGSY or Golden Jubilee Rural Self-Employment 
Scheme. To begin with, I provide a brief note on poverty alleviation policy, the specific objectives of the SGSY, and the politics of development policy in India.

Major nation-wide anti-poverty initiatives were first introduced in the Fourth Five Year Plan (1969-74). The SGSY, initiated in 1999, is a major addition to India's evolving policy on poverty ${ }^{11}$. It has replaced the so-called 'flagship' of this policy the Integrated Rural Development Programme (IRDP) (Mathur 1995). By providing income-generating assets to the rural poor who are unemployed and lack substantial productive assets like land, the SGSY aims to provide sustainable employment opportunities and bring its beneficiaries Above Poverty Line (APL). When they are selected for the SGSY, beneficiaries are officially 'Below Poverty Line' (BPL). This means that they have met certain criteria such as having per capita expenditure and asset ownership below a certain minimum level ${ }^{12}$ in a survey to assess BPL families that is conducted in each Indian province at the beginning of a Five Year Plan period. While it also benefits individuals, the focus of the SGSY is poverty alleviation through the formation of Self Help Groups (SHGs). At first, SHGs generate microcredit through their credit and thrift function. Once an SHG has sufficient funds, the government facilitates the start-up of group-based micro-enterprises through vocational training in the chosen group activity, and through bank loans and subsidies. Micro-enterprises promoted by the SGSY can range from animal husbandry to weaving to the preparation and sale of processed foods like pickle, etc. (GoI 1999). The SGSY aims to focus on vulnerable rural groups such as lower-caste women.

For a country in which poverty alleviation and rural development are important objectives, the SGSY can be an important developmental tool. Yet, like all

\footnotetext{
${ }^{11}$ For more on India's poverty alleviation policy, and different analytical perspectives for studying it, see Kohli 1987, Gaiha 1991, Vaidyanathan 1995, Hirway 2002 and Kozel 2003

${ }^{12}$ For Gujarat, the per capita monthly expenditure limit for being considered BPL for the Ninth Five Year Plan (1997-2002) was Rupees 254, where GBP 1 approximates Indian Rupees 80 (Jha 1997).
} 
policy, the SGSY is political (see Schaffer 1984), and the BJP is deploying it as a political tool. There is ample literature on the setting of agendas, the building of patronage structures, and the acquiring of rents and political power, etc. through control of policy by governments headed by different political parties in various Indian provinces (Mooij 1996, Sengupta 1998). It is not the brief of this paper to look at the diverse kinds of politics that may be played out in the SGSY programme. As the earlier section on concepts indicated, I intend to look at the specific politics of the SGSY's implementation in a province governed by the Hindu Right, which creates certain effects. These effects include (a) the exclusion of non-Hindus, (b) the inclusion of lower and backward castes and the construction of their identities as 'Hindu', and (c) contestation over identity related to the question, who is a Hindu? Each of these variables is discussed in the remainder of this paper. According to Gujarat's Minister for Rural Development, the aim of his government is 'to reach out to the maximum number of people' through the SGSY (KM, interviewed 13/8/02). Indeed, this aim seems to have been achieved, if we are to believe figures furnished by the Minister, according to which Gujarat surpassed its target of 50,000 SHGs for 2001-2002, and formed 67,000 instead. Yet, the formation of SHGs in Gujarat is not undifferentiated. It involves a highly political process surrounding the question, who will be an SGSY beneficiary? The BJP-led government in Gujarat has made every effort to exclude religious minorities from its development projects (Sud 2003). This systematic exclusion differentiates its development agenda from that of previous governments because it calls into question the status of Gujarat's religious minorities as members of the Indian nation-state.

The three villages researched, Ekgam, Bijapol and Trijapur, have a combined population of around 15,000 . Within this, the number of households with BPL 
certificates in 2002 was 694, 96 and 607 respectively. The number of Muslims with BPL status was 0, 1 and 1 (APO 2002). Given that the SGSY is aimed at people below poverty line with no employable assets such as land, it is not surprising that there is not one Muslim SGSY beneficiary in these villages. Muslims, comprising 2.98 per cent of the population of Gandhinagar administrative block, are after all mostly agriculturalists, shopkeepers and skilled artisans, with some landless labourers (Directorate of Census Operations 1991, Patel 2002). None of these, except the latter, are the usual occupational target groups of the SGSY. At the same time, it should be noted that of the 138 SHGs in Gandhinagar block in 2002, 74 have members who are officially Above Poverty Line (TDO 2002). In addition, judging from visits to several SGSY SHG members in the three villages researched, it may safely be said that many people who possess BPL certificates are not actually BPL at all. They have brick and concrete houses, electrical appliances, regular employment and an income level that does not officially qualify them as BPL. Yet they possess BPL certificates. But this 'politics of policy' wherein one's access to the state's development programmes is influenced by one's connections with the powerful and not necessarily by need, poverty or powerlessness, is not unique to Gujarat under the BJP. It has just been briefly cited to indicate that the failure of religious minorities to find their way into the SGSY is only partly a function of their being classified as skilled artisans, and shopkeepers, etc. Actors such as government officials who shape the SGSY in Gandhinagar offer interesting alternative explanations for the lack of Muslims or Christians in Gujarat's rural development programmes.

The reasons given by officials for non-inclusion of religious minorities in the SGSY do not concern this group's occupational or income characteristics. According to an officer of the Gandhinagar District Rural Development Agency, the negligible 
number of non-Hindu BPL certificate holders generally get excluded from SHGs because 'groups are kept as homogenous as possible to ensure cooperation among members' (JP, interviewed 11/9/02). Thus, the three villages researched had 12 of Gandhinagar administrative block's 138 functioning SGSY SHGs, each with 12 to 20 members. Several of these groups were named after Hindu religious deities. For instance, 'Chamunda Swa Sahay Juth' (Goddess Chamunda SHG), 'Jay Jogeshwar Swa Sahay Juth' (Hail Lord Jogeshwar SHG) and 'Jay Jogni Ma Swa Sahay Juth' (Hail Mother Goddess Jogni SHG) (TDO 2002). The influence of local village politicians, mostly from the BJP, which dominates Gandhinagar politics, on the naming and running of these SHGs is significant. Government officials managing the SGSY, local politicians and SGSY beneficiaries themselves ensure that the SGSY SHGs are kept as homogenous and 'Hindu' as possible. There is little in these groups that would attract religious minorities. Their exclusion from homogenised development programmes is only one level of the agenda of 'othering' by the Sangh Parivar and the government that it controls. Another, perhaps more pernicious form of exclusion is the denial of the very existence of religious minorities in Gandhinagar.

According to a village-level worker in charge of the SGSY in two of the three villages under study, Muslims and Christians are absent from this programme because 'there are no non-Hindus in Gandhinagar block' (MN, interviewed 26/8/02). The demographic figures above indicate that this statement is inaccurate. A revenue official from the village of Ekgam went one step further when he asserted that there was no evidence of non-Hindus in rural development programmes because there are no non-Gujaratis in this village ( $\mathrm{T}$, interviewed $8 / 9 / 02$ ). It was difficult for me to gauge the number of non-Hindus in the villages researched in mid-2002, when fieldwork was conducted. The February-April 2002 massacre of Muslims was fresh in 
everyone's memory. Villagers were not ready to talk about religious minorities. Many Muslims living in rural areas of Gandhinagar district had temporarily migrated to other provinces or urban areas for safety. Officials denied their existence. I know that there was a small Muslim population in each of these villages because I came across some households while doing research. Moreover, the government itself has certified at least 2 Muslim households in the three villages researched as BPL, as noted above. The lack of inclusion of religious minorities in Gujarat then is not simply a function of numbers and electoral calculations. At one level, the government has attempted to construct 'homogenous' Self Help Groups for the smooth implementation of development policy. Being numerical minorities, Muslims or Christians have little chance of making it into this homogenising development ambit. At another level, officials and ruling party politicians deny the very existence of non-Hindus in Gandhinagar. By calling these non-Hindus 'non-Gujarati', members of the Gujarat government are excluding them from Gujarat's Hindu rashtra or Hindu nation-state. The specific pattern of the implementation of poverty alleviation policy in Gandhinagar, then, fits into the wider Hindutva agenda of making Gujarat Hindu.

I have so far shown that the government's control of development programmes facilitates the Hindutva agenda of 'othering' religious minorities. While the latter is an example of negative disrimination, the BJP-led government in Gujarat also indulges in 'positive' discrimination through its development programmes. Thus, discriminating against some sections of the population solidifies the boundary around the government's 'chosen development constituency'. Lower-caste Dalits, Adivasi tribals and other backward-caste Hindus are acknowledged as residents of a village by the simple and important process of being considered for 'Below Poverty Line' certificates and government development schemes. The main contention of this paper 
- that the government has used development to build a Hindu constituency, which can be the potential base for forging upper- and lower-caste Hindu unity - is further substantiated through the example of Gujarat's shifting BPL census figures. For the Ninth Five Year Plan (1997-2002), the BPL survey carried out by all District Rural Development Agencies in Gujarat in 1997-98 revealed that of a rural population of $55,87,768$ families, $19,80,879$ or 35.45 per cent of families were BPL (Director of Rural Development 2002). However, since the production of these figures, Gujarat's BPL list has been revised twice. The BPL figures that these revisions have produced are presented in Table 1 below.

[Table 1 to be inserted about here]

Considering that the BPL survey is carried out once for every Five Year Plan, the production of widely varying sets of BPL figures in three consecutive years, as shown in Table 1, is extraordinary. It would appear that Gujarat's population of the very poor, those categorised as Below Poverty Line, rose sharply between 1998 and 2001. Interestingly, one cannot attribute the above figures to a war, drought, or other such factor. Instead, behind the repeated BPL surveys in the province lies an interesting story of policy and politics. Implicated in this story are several actors from regional and village-level politicians, to caste leaders, and potential development beneficiaries. Petty bureaucrats explain the variableness of BPL figures for the Ninth Plan in Gujarat as gadbad, roughly translated as "mischief and manipulation" (SP, interviewed 2/9/02; SK, interviewed 11/9/02). They recall the intense level of bargaining that followed the 'first BPL survey' in Gujarat in 1998. With around 65 per cent of the rural population left out of the BPL list, officials and politicians faced a barrage of representations and letters. Caste leaders, village heads and potential 
development beneficiaries protested that members of their caste or families had been unfairly left off the list. Thus, they would be unable to access government schemes for, say, subsidised food and other development projects. They demanded BPL status. Conceding to the pressure from these groups, the Gujarat government ordered a 'revision' of the BPL list. That is, groups that had protested at being left out of the BPL list and potential development benefits were accommodated. This accommodation was substantial because the percentage of BPL families in Gujarat was revised from 35.45 to 40.39 . Declaration of a revised BPL list invited renewed protests in 2000-2001 from those who were still not on the list. With an eye on the upcoming elections in 2002, the province's political leaders again ordered revision of the list. In 2001, the BPL figure for the state stood at 52.32 per cent.

Not surprisingly, the District Rural Development Agency in Gandhinagar received the maximum number of demands for inclusion in the BPL list from the Rawal and Parmar castes (SK, interviewed 20/9/02). The backward-caste Rawals ${ }^{13}$ and lower-caste Parmars ${ }^{14}$ are well represented in the SGSY. They also have a growing political voice. They are represented in local self-government bodies that the BJP controls in many villages of Gandhinagar district. For instance, the chief negotiator for the Rawal community in Ekgam village for the SGSY scheme is a village school clerk. He is also a member of the village panchayat or governing council. The fact that groups like the Rawals and Parmars fit into the government's desired 'Hindu' constituency has given them added leverage and bargaining power.

\footnotetext{
${ }^{13}$ In Gandhinagar district, traditionally, Rawals have been camel keepers and herders. Today, among the better-off Rawals, camels have been replaced by auto rickshaws, which are used for transporting goods and people between villages, and in the towns of the district.

${ }^{14}$ The Parmars are involved in varied occupations in Gandhinagar. They may be landless labourers, petty traders, and even government employees. Several members of this sub-caste are part of the emergent lower-caste Dalit middle class in Gujarat, having benefited from reservations in public jobs and education. In fact, one of Gandhinagar's seven Village Level Workers is a Parmar, and 10 out of 182 members of the present Gujarat legislative assembly are Parmars.
} 
There is of course a link between the province's development programmes and the Sangh Parivar organisation at the levels of the village and local government - the middlemen who argued the Rawals' and Parmars' cases for inclusion in the BPL list in the offices of the Government of Gujarat were often village-level politicians members of the BJP and other Sangh Parivar organisations. Thus, while the government, with the BJP at its helm, went out of its way to accommodate some groups in its BPL census, and then in schemes such as the SGSY, it has succeeded in keeping others out. One sees here the merging of the desire of groups like the Rawals and Parmars to be included in the political and developmental stakes of the BJP-led government in Gujarat, the latter castes' aspirations for social mobility, the Sangh Parivar's objective of acknowledging these groups as its Hindu constituency, and the channelling of political patronage to these groups - not just because they are a populous electoral constituency but also because they are from the coveted ethnoreligious group of Gujarati-Hindus.

'We can recognise a Waghri from his chaal' Gujarat

So far, I have depicted one part of the story of exclusion of religious minorities and the inclusion of lower- and backward-caste groups into the development fold. The wider aim of this process is to attract the latter groups to the larger worldview of 'one Hindu nation, one Hindu people, one Hindu culture' that many actors in the governmental and political spheres espouse. The previous section, then, explored the 'construction'- through exclusion and inclusion - of a certain kind of 'Hindu Gujarat'. I now come to the second aspect of this story, which begins with

\footnotetext{
${ }^{15}$ Gait
} 
the question, are attempts to forge a unified Hindu community in Gujarat uncontested? Theoretically, the guiding question of this section can be placed within anthropological studies of 'contested identity', which suggest that identity is influenced by the 'communal' and the 'cultural', and its formation may be affected by a wide range of 'contested' experiences, involving singly or in conjunction with others, gender, ethnic, class, regional, religious, professional and national affiliations. Moreover, identity cannot be defined as a state of being but of becoming. (Wicker 1997: 17-19). Anthropologists therefore also like to speak of 'contesting identity' to indicate the ongoing, unresolved quality of the social experience that is being researched (Schwartz 2001). If identity-formation is a continuing process, then the boundaries of identity are continuously changing and being negotiated. This theoretical insight, of course, is the exact opposite of the Hindutva project that seeks to build an essentialised 'Hindu' identity based on the notion of a frozen history and frozen sense of community. That is, the Hindu Right seeks to build a community of those who have a 'holy land' and 'motherland' in common, but seeks to ignore alternative markers of identity such as class, gender, caste, status, belief, history, etc. within so called 'Hindus'. What I am attempting to look at now is the manner in which the Hindu Right's quest for 'a' Hindu-Gujarati identity plays out in the context of contests over power and resources in micro-fieldwork sites where the Hindutva project is being operationalised. Moreover, while identity, as the above-mentioned anthropological theories suggest, may be influenced by various 'contested experiences', this paper concentrates on caste status as a contested category in the Hindu Right's attempts to forge a Gujarati-Hindu unity ${ }^{16}$.

\footnotetext{
${ }^{16}$ Scholars have looked at other contested experiences such as gender in the Hindutva project. See for instance, Chachhi (1989) and Sarkar (1993)
} 
Previous sections mentioned how upper castes, supported by the Sangh Parivar, participated in anti-reservation violence against lower castes in Gujarat in the early 1980s. The mid-1980s saw a change in the position of the Hindu Right, which realised that attracting lower and backward castes and Adivasi tribals to the Hindutva fold was a good ideological and electoral strategy. The BJP-led government that has since come to power has taken concrete steps to include these groups in its development programmes. Yet these findings do not prove that the entire machinery of the Sangh Parivar, which continues to be dominated by upper castes, has accepted ideas of tribals, lower and backward castes as Hindus and equals. Have the ordinary cadres of the Hindu Right gone from attacking Dalits in the 1980s to enthusiastically accepting them as fellow Hindus twenty years later? One indication that Gujarat today is witnessing two simultaneous processes in the move towards a Gujarati-Hindu identity - construction as well as contestation - is found in the violence of 2002. The participation of lower-caste Dalits and Adivasi tribals, including communities like Waghris, Thakardas and Charras, in attacks on Muslims has been widely discussed (Shah 2002). However, relatively little has been written about discrimination by Hindutva organisations against the lower castes and tribals whose properties were damaged or who sustained injuries during the 2002 violence. According to a volunteer with the secular people's organisation Aman Ekta Manch, who worked in the Vatva relief camp near Ahmedabad, Waghris, who are at the bottom of the hierarchy of the backward castes, were not allowed to take shelter in relief camps set up for Hindus by Sangh Parivar organisations. 'Desirable' yet shunned groups in the making of Hindu Gujarat then had to turn to relief camps like Vatva that were predominantly sheltering Muslims (Upadhyay, personal communication). We also know that after Muslims, low-caste Dalits suffered the highest casualties in the violence of 2002 (Raj 2002). 
Dalits, then, were aggressors at some sites of the Gujarat violence, but were victims in others. The implication of this is that the question, who is a Hindu according to the Sangh Parivar and its cadres, is being contested and debated at various sites in Gujarat even today.

The above paragraphs represent the broad context of the construction of, as well as contestation over, the question of the Gujarati-Hindu identity. The main aim of this paper, however, has been to look at the latter through the development programmes of the Gujarat government. Reverting to the example of the SGSY in villages in Gandhinagar district, one can detect evidence of contestations over the building of the Hindu constituency. Even though the government's Village Level Workers (VLWs) have been instructed to form SHGs as part of the SGSY scheme amongst lower and backward castes and tribals, all sub-castes within the latter groups are considered incapable of being development beneficiaries. As the VLW in Ekgam and Trijapur villages informed me, groups like Waghris and Thakardas are too poor and illiterate to run an SHG. Therefore they cannot be considered for SGSY benefits (MN 24/9/02). Moreover, as members of the Waghri community told me in Ekgam and Bijapol villages, to be considered for development benefits, one needs to have contacts among the local and sub-regional politicians from the ruling party. The Waghris are poor and not well connected politically, so they cannot bribe politicians or government representatives (WA, interviewed 9/9/02 and WS, interviewed $12 / 9 / 02)$. Thus, merely being perceived, in theory, to be a member of the evolving Hindutva coalition does not make Waghris or other similarly poor and low-status groups eligible for favourable consideration by the BJPs politicians or government bureaucrats. On the other hand, as the previous section indicated, numerically powerful and politically upwardly mobile backward- and lower-caste groups like 
Rawals and Parmars may have made it onto the development benefit ladder in Gandhinagar district, propelled by the BJP government and the Hindu Right's desire to woo them as 'Hindus'.

But along with the construction of a unified Hindu electoral constituency and socio-political identity are contests over power, resources and caste assertion. Caste as a form of social division is historically and structurally embedded in the government machinery and in the dispositions of local politicians who 'unofficially' facilitate beneficiary selection in development programmes. That this impedes the smooth construction of a united Gujarati-Hindu identity is further evident in the loaded statement of a pro-Hindu Right government official in Gandhinagar district:

\footnotetext{
We do not choose Waghris for government programmes like the SGSY because they cannot sustain an SHG. If an upper caste Patel walks into our office and asks for some benefits, we may consider him. He can carry out responsibility. If however, a low status Waghri or Thakore comes to this office, we behave differently than we would towards the Patel or Brahmin. We can recognise a Waghri from his chaal (gait).
}

(T, interviewed 8/9/02)

For the official quoted above, the meekness and lack of confidence of a Waghri, evidenced in his/her gait, set him/her apart from the Brahmin or Patel, with his/her self-assured stride. The defining identity characteristic for the official is not these groups' so-called common 'Hinduness' but their very obviously different castes. Judging by the statement of the Waghris left out of the SGSY, quoted above, their inability to pay bribes also influences the latter official's attitudes to the potential beneficiaries of development programmes. 
Quite clearly, the agents of the 'Hindu rashtra' are embedded in various structures and experiences. A blanket order to favour lower-caste 'Hindus' cannot obliterate their previously learned experiences of implementing development policy. Thus, the Hindu Right faces various structural impediments in its attempts to build Hindu unity. Caste, a focus of this paper, is probably one of the foremost. Contemporary Gujarat, then, is witnessing both the construction of and contestation over the Gujarati-Hindu identity.

\section{Conclusion}

In the introduction, this paper set out a working interpretation of the term 'Hindu', based on literature produced by the Sangh Parivar. The rest of the paper then discussed how the Hindu Right in Gujarat has made determined efforts to construct a Gujarati-Hindu ethno-religious unity and to project itself as the representative of all 'Hindus'. Yet, the Hindutva movement's history of upper-caste leanings, evident in the caste violence of 1981 and 1985, has not been shaken off. Despite symbolic gestures like the Ekatmata Yatras, or Hindu unity processions, of 1983 and 1995, and more concrete actions like the use of the BJP government's development resources to woo the lower-caste constituency, Gujarati-Hindu unity is proving to be elusive for the Hindu Right. The latter's own cadres continue to show tremendous bias against the lower and backward castes and Adivasi tribals. This raises questions about the viability of the Hindutva project's ambitions of constructing a Hindu Gujarat.

As a conclusion to this paper, it is important to make two further points, which also indicate directions for future research. This paper has attempted to unpack the construction of a Gujarati-Hindu identity in practice. It took the theoretical concept of a unified Hindu identity based on ideas of India as a Hindu 'Holy land' and 
'Motherland' as given. It would be incorrect to believe, however, that the Hindu nationalist movement has reached some sort of consensus over what it means to be Hindu and is only facing problems in operationalising this concept. In fact, if one explores the literature of the many affiliates of the Sangh Parivar in even a rudimentary way, it becomes clear that there are contests even over definition. There is lack of consensus, then, not just amongst Hindutva cadres and government officials in Gujarati villages; the lack of consensus also exists among those who lay out the framework through which the Hindutva project is supposed to operate. Thus a Hindutva thinker on the 'Global Hindu Electronic Network' states that 'the caste system can be justified. That it has survived for centuries proves it is useful' (Harshananda, http://www.hindubooks.org/hinduqa/author.htm, accessed 25/4/04). On the other hand, the Joint Secretary of the cultural wing of the Hindu Right - the VHPcalls caste a 'disease' of the Hindu world (Joshi, www.vhp.org, accessed 25/4/04). Caste is not the only contested social division in the Hindutva stable. Conceptualisations of the religious 'other' are also being debated. Thus, Hindutva ideologue Murli Manohar Joshi raised eyebrows in the Sangh Parivar by calling Indian Christians 'Christi Hindus' and Indian Muslims 'Mohammadiya Hindus' in 1991 (quoted in Kaur 2001). Of course, in the strict Savarkar definition of 'Hindu', and certainly for Gujarat's Hindutva extremists like Chief Minister Narendra Modi, the Christian and Muslim 'other' can never be 'Hindu'. The question 'who is a Hindu' is being debated today not just in the Sangh Parivar but also in main opposition parties like the Congress. In fact, even some Muslim leaders have been forced to think about this issue. But what different Hindutva groups think about this definitional question, and certainly what groups outside the Hindutva movement think, is a largely unexplored question. 
The preceding statements may seem less surprising if one attempts to understand them alongside Simpson's work in Kachchh, north western Gujarat (2004). He suggests that there are different organisations and shades of opinion among those who vote for the BJP and support the Hindutva movement, pertaining to, for example, ideal caste configurations and what inter-caste/non-caste relationships should look like. There are also differences in objectives, constituencies, agendas, etc. In other words, what often looks like a 'movement' is not really so at all. That is, the 'juggernaut' is, in fact, a series of smaller but different things that are often depicted as if they were one. Of course we need much more research to know, with any clarity, about the large but often disparate forces of India's Hindu Right. But as was indicated in the introduction, sweeping statements about the power and invincibility of the Hindutva juggernaut need serious and detailed unpacking. Without the latter, neither meaningful scholarship and discussion, nor constructive and progressive activism, seem possible. 


\section{References}

AIFOFDR- All India Federation of Organisations for Democratic Rights (1999) Then they came for the Christians. A report to the nation. Bombay: AIFOFDR

APO (Additional Project Officer) (2002) 'BPL figures in villages of Gandhinagar block', Information Sheet, Gandhinagar: District Rural Development Agency

Attri, S.P. (1999) 'Procedure for Donating Money to VHP Shuddhi Program', Shri S.P. Attri's Editorials, February 14. www.hinduunity.org, accessed 16/4/04

Awaaz- South Asia Watch (2004) 'Appendix 5: Women, Dalits, Adivasis and the RSS', In Bad Faith? British Charity and Hindu Extremism. London: Awaaz South Asia Watch Ltd.

Bardhan, P. (1997) 'Corruption and Development: A Review of Issues', Journal of Economic Literature, Vol. 35, September. Pgs. 1320-1346

Chhachhi, A. (1989) 'The state, religious fundamentalism and women: Trends in South Asia', Economic and Political Weekly, $18^{\text {th }}$ March

Communalism Combat (2000) 'Wooing the victim', Communalism Combat. September. http://www.sabrang.com/cc/comold/sep00/cover.htm, accessed 15/4/04

Corbridge, S. and J. Harriss (2000) Reinventing India. Liberalization, Hindu Nationalism and Popular Democracy. Cambridge: Polity Press

DRDA (District Rural Development Agency) (2002) 'Gandhinagar jillana talukavar BPL kutumboni punah chakasani bad aakhri thayel kutumboni mahiti darshavati tarij', Unpublished Information Sheet. Gandhinagar: District Rural Development Agency (In Gujarati)

Dave, Mr. Justice V.S. (1990) Report of the Commission of Inquiry into the incidents of violence and disturbances which took place at various places in the state of Gujarat since February, 1985 to $18^{\text {th }}$ July, 1985. Ahmedabad: Government of Gujarat

Desai, R. (2002) 'Blazing Gujarat: The Image of India's Future?', Akhbar, No. 2, February-March, http://www.indowindow.com/akhbar/article.php?article=94\&category $=5 \&$ issue $=16$, accessed 26/4/04

Director of Rural Development, Government of Gujarat (2002) 'BPL figures for Gujarat for the Ninth Five Year Plan', personal communication

Directorate of Census Operations (1991) 'Religion, Gujarat. Table C-9' http://censusgujarat.gswan.gov.in/

Diwanji, A. (2003) 'The search for the soul of Hindutva', rediff.com, January 7 
Elst, K. (2002) Who is a Hindu? : Hindu Revivalist Views of Animism, Buddhism, Sikhism and Other Offshoots of Hinduism. New Delhi: Voice of India

Gaiha, R. (1991) 'Poverty Alleviation Programs In Rural India- An Assessment', Development and Change, Vol.22, No.1. Pgs. 117-154

Gonsalves, F. (2000) 'Saffron shrouds YKJ 2000 in Gujarat', Communalism Combat. January

Government of Gujarat (2002) SGSY Beneficiary Form Gandhinagar district. Gandhinagar: Government of Gujarat

Government of India (1999) Swarnajayanti Gram Swarozgar Yojana. Guidelines. New Delhi: Ministry of Rural Development

Hardiman, D. (1981) Peasant Nationalists of Gujarat. Kheda District 1917-1934. Delhi: Oxford University Press

Harriss-White, B. (1997) 'Informal Economic order: Shadow States, Private Status States, States of Last Resort and Spinning States - a speculative discussion on South Asian case material', QEH Working Paper SO6, Oxford: Queen Elizabeth House

Harshananda, Swami (no date) Hinduism through questions and answers. http://www.hindubooks.org/hinduqa/author.htm, accessed 25/4/04

Hindu, The (2002) 'Continued provocation', Editorial. September 25. http://www.hinduonnet.com/thehindu/2002/09/25/stories/2002092501061000.htm, accessed 29/4/04

Hirway, I. (2002) How Far Can Poverty Alleviation Programmes Go? Assessment of PAPs in Gujarat, sponsored by the Planning Commission of India. Ahmedabad: Centre For Development Alternatives

Hirway, I. and Mahadevia, D. (2003) Human Development Report. Gujarat 2003. Part I. Ahmedabad: Mahatma Gandhi Labour Institute

Human Rights Watch (2002) "We have no orders to save you" State Participation and Complicity in Communal Violence in Gujarat', Human Rights Watch, Vol. 14, No.3 (C)

IIJ (2003) 'Threatened Existence: A Feminist Analysis of the Genocide in Gujarat', Report by the International Initiative for Justice, December 2003. www.onlinevolunteers.org. Accessed 11/2/04

Iyer, V.R.K., Sawant, P.B., Suresh, H., Kannabiran, K.G., Roy, A., Subramanian, K.S., Shah, G., Sarkar, T. (2002) 'Patterns of Violence', in Crime Against Humanity. An Inquiry into the Carnage in Gujarat, Concerned Citizens Tribunal. Mumbai: Citizens for Justice and Peace 
Jalal, A. (1998) 'Exploding Communalism: The Politics of Muslim Identity in South Asia' in Bose, S. and Jalal, a. (Eds.) Nationalism, Democracy and Development: State and Politics in India. http://www.tufts.edu/\%7Eajalal01/Articles/communalism.pdf Accessed 16/3/04

Jha, A.K. (Joint Director, Integrated Rural Development) (1997) 'Poverty line for BP1 Census’ No. M-28012/16/91- IRD III, September 10. New Delhi: Ministry of Rural Areas and Employment

Joshi, M. (no date) 'Religious Regeneration the Only Solution to Various National Problems', www.vhp.org, accessed 25/4/04

Kaur, N. (2001) 'Voices from the Far Right', Frontline. Volume 18, Issue 16, August 4-17. http://www.flonnet.com/fl1816/18160300.htm, accessed 25/4/04

Kohli, A. (1987) The State and Poverty in India. The Politics of Reform. Cambridge: Cambridge University Press

Kozel, V. et al (2003) 'Poverty Measurement, Monitoring and Evaluation in India. An Overview' Economic and Political Weekly. January 25. Pgs. 296-301

Macwan, J. (2002) 'This 'unique' land', Seminar, No. 513, May. http://www.indiaseminar.com/2002/513/513\%20joseph\%20macwan.htm, accessed 26/4/04

Mathur, K. (1995) 'Politics and Implementation of Integrated Rural Development Programme', Economic and Political Weekly October 14-21. Pgs. 2703-2708

Mooij, J.E. (1996) Food Policy and Politics. The Public Distribution System in Karnataka and Kerala, South India. Wageningen: Faculty of Politics and SocialCultural Sciences

Mukta, P. (2002) 'On the Political Culture of Authoritarianism', in Shah, G., Rutten, M., and Streefkerk, H. (Eds.) Development and Deprivation in Gujarat. In Honour of Jan Breman. New Delhi: Sage Publications. Pgs. 59-73

Nandy, A., S. Trivedy, S. Mayaram, A. Yagnik (1995) Creating a Nationality. The Ramjanmabhumi Movement and Fear of the Self. Delhi: Oxford University Press

Pai, S. (2002) Dalit assertion and the unfinished democratic revolution: the Bahujan Samaj Party in Uttar Pradesh. Delhi: Sage Publications

Pandey, G. (1990) The Construction of Communalism in Colonial North India. Delhi: Oxford University Press

Parekh, M.G. (1994) 'Third General Elections in Gujarat- Some Significant Trends', in Grover, V. and Arora, R. (Eds.) Development of Politics and Government in India, Vol. 5 (1959-1964). New Delhi: Deep and Deep Publications. Pgs. 579-588

Raj, U. (2002) 'Dalits are forced and enticed to fight against Muslims in Gujarat', Press Statement. April 6. 
http://www.sabrang.com/gujarat/statement/statement.htm\#udit\%20raj, accessed $19 / 4 / 04$

Rudolph, L.I. and Rudolph, S. H. (1987) In Pursuit of Lakshmi. The Political Economy of the Indian State. Chicago: University of Chicago Press

Sanghavi, N. (1996) Gujarat. A Political Analysis. Surat: Centre for Social Studies

Sarkar, T. (1993) 'The Women of the Hindutva Brigade', Bulletin of Concerned Asian Scholars, Vol.25, No.4

Savarkar, V.D. (1923) Hindutva. Delhi: Bharati Sahitya Sadan

Schaffer, B. (1984) 'Towards Responsibility: Public Policy in Concept and Practice' in Clay, E.J. and Schaffer, B.B. (Eds.) Room for Manoeuvre. An exploration of public policy planning in agricultural and rural development. London: Heinemann Educational Books. Pgs. 142-190

Schwartz, J. (2001) "Contested Identity" or "Ethnic War"? The Endurance Test in the Republic of Macedonia', Paper presented at the MESS Conference: "Macedonian Knots", Piran, Slovenia, September 20. www.anthrobase.com, accessed 16/4/04

Sengupta, A. (1998) 'Embedded or Stuck? The study of the Indian state, its embeddedness in social institutions and state capacity' Unpublished MPhil Thesis. Oxford: Queen Elizabeth House

Shah, G. (2002) 'Caste, Hindutva and the Making of Mob Culture', in S. Varadarajan (Ed.) Gujarat. The Making of a Tragedy. New Delhi: Penguin Books India. Pgs. 416426

Shani, O. (2001) 'The Making of Ethno Hinduism in India: Communalism, Reservations and the Ahmedabad Riots of 1985. Cambridge' Unpublished PhD Thesis. Cambridge: University of Cambridge

Sheth, P. (1998) Political Development in Gujarat. Ahmedabad: Karnavati Publications.

Sikand, Y. (2004) 'Book Review: The Path of the Parivar: Articles on Gujarat and Hindutva, by Mukul Dube', The Milli Gazette. 16-31 March

Simpson, E. (2004) 'Hindutva' as a Rural Planning Paradigm in Post-earthquake Gujarat', in J. Zavoz, A. Wyatt and V. Hewitt (Eds.) The Politics of Cultural Mobilization in India. New Delhi: OUP. Pgs. 136-165

Sud, N. (2003) 'Acting on Development: Exploring the interface of policy and its stakeholders in Gujarat, India', Unpublished MPhil thesis, Oxford: Queen Elizabeth House

TDO (Taluka Development Office) (2002) 'Names and bank numbers of Gandhinagar Block SHGs', Information Sheet, Ganghinagar: Taluka Development Office 
Thapar, R. (1989) 'Imagined religious Communities? Ancient History and the modern search for a Hindu identity', Modern Asian Studies 23, 2, Pgs. 209-231

Vaidyanathan, A. (1995) 'The Political Economy of the Evolution of Anti-Poverty Programmes' in Satyamurthy, T.V. (Ed.) Industry and Agriculture in India since Independence. Volume 2. Delhi: Oxford University Press

Viswanathan, S. (2006) 'Two promises and an opportunity', Frontline, Vol. 23, Issue 8. April 22-May 05, http://www.hinduonnet.com/fline/fl2308/stories/20060505004902400.htm, accessed $25 / 7 / 06$

Wicker, H-R. (Ed.) (1997) Rethinking nationalism and ethnicity: the struggle for meaning and order in Europe. Oxford: Berg

Yagnik, A. (2002) 'The Pathology of Gujarat', Seminar No. 513. May. Pgs. 19-22

$\underline{\text { Interviews }}$

BV (interviewed on 26/8/02, Taluka Development Office, Gandhinagar), Village Level Worker, Gandhinagar Block

JP (interviewed 11/9/02, Gandhinagar DRDA office) Gandhinagar District Rural Development Authority

KM (interviewed on 13/8/02, Gandhinagar Secretariat) Gujarat Minister of State for Rural Development

MN (interviewed on 26/8/02 and 24/9/02, village Ekgam) Village Level Worker, Gandhinagar Block

SK (interviewed on 11/9/02 and 20/9/02, Gandhinagar DRDA office) Gandhinagar District Rural Development Authority

SP (interviewed on 2/9/02, Gandhinagar Secretariat) Officer, Rural Development Department, Government of Gujarat

$\mathrm{T}$ (interviewed on 8/9/02, village Ekgam) Village Revenue Officer, Ekgam

WA (interviewed 9/9/02, village Ekgam) Unemployed, occasional daily wage earner

WS (interviewed 12/9/02, village Ekgam) Unemployed 
[Table 1, to be inserted in the paper on Page 20]

Department of Rural Development Figures for People Below Poverty Line in Rural Gujarat

\begin{tabular}{|l|l|l|l|}
\hline \multicolumn{1}{|c|}{ Year } & $\frac{\text { Rural population }}{\frac{\text { (Number of }}{\text { families) }}}$ & BPL Families & Percentage of \\
\hline $1998-1999$ & 5587768 & 1980879 & 35.45 \\
\hline $\begin{array}{l}\text { BPL families } \\
\text { (Government of Gujarat revised } \\
\text { figures, said to be "tentative") }\end{array}$ & 5766738 & 2329378 & 40.39 \\
\hline $\begin{array}{l}\text { 31.12.2001 Gujarat } \\
\text { (Government of } \\
\text { "rechecking") }\end{array}$ & 6028999 & 3154297 & 52.32 \\
\hline
\end{tabular}

Table 1. Source: Director of Rural Development, Government of Gujarat (2002) 